\title{
"The Effect of Tranexamic Acid on Blood Loss during Total Knee Arthroplasty"
}

\author{
${ }^{1}$ Jagadish Surannavar; ${ }^{2}$ Harsharaj K.; ${ }^{3}$ Rajesh s.; ${ }^{4}$ Edward Nazareth \\ ${ }_{1,2,3,4}$ Department of Orthopaedic Surgery, Fr. Muller Medical College, Mangalore-575002.
}

\begin{abstract}
:
Background: Tranexamic acid is antifibrinolytic drug which has the property to reduce intraoperative and postoperative bleeding. There are several studies supporting the use of tranexamic acid in total knee joint replacements and few in total hip replacements. This study was intended to establish the effects of tranexamic acid in minimizing the intra operative and post operative blood loss in total knee arthroplasty.

Material and methods: This was a prospective follow up study conducted in Father Muller Medical College , Mangalore over period of 4 months from August 2013 to November 2013. A total number of 30 patients who underwent total knee arthroplasty were included for this study. The patients were grouped as treatment and control group. The treatment group and control group were selected by purposive sampling. In the treatment group, the patients undergoing total knee arthroplasty received single dose of intravenous tranexamic acid $10 \mathrm{mg} / \mathrm{kg}$ body weight 5 minutes before skin incision and equal volume of saline was injected in the control group. Intra operative blood loss was calculated by galvanometric method ${ }^{20}$, weighing the sponges used and soiled by blood during surgery and measuring the amount of blood collected in suction apparatus used during the surgery.

The haemoglobin level assessed post operatively and compared with preoperative haemoglobin level. The amount of fluid collected in the post-operative drain were also measured. All the collected data are analyzed with Fisher exact test.

Conclusion:Tranexamic acid administrated before surgical incision is efficient in reducing bleeding during common surgeries around the hip joint. Especially surgery where more amount of blood loss was expected, like total joint replacement and hemiarthroplasty, the drug had shown significant benefit compared with the control group.
\end{abstract}

Key words: Tranexamic acid, Blood loss, Haemoglobin level.

\section{Introduction}

Most of the major orthopaedic surgeries normally result in significant blood loss which increase the morbidity and mortality especially in patients whose haemoglobin level is low prior to surgery. As a result, the blood loss in the elective orthopaedic surgeries results in transfusion rates that vary from $11 \%$ to $65 \%$, depending on type of surgery ${ }^{1}$. The blood transfusion is a life saving measure in hemorrhage but it is expensive, resource is rare and transfusion is involved with varied hazards. The risk of infection, immune suppression, allergic manifestations, anaphylaxis, volume over load, transfusion-related lung injury, and graft versus host reactions etc. are not uncommon even with compatible transfusions ${ }^{2}$. The packed red cells can cause hypothermia and coagulopathy. There are some people, who refuse blood transfusion because of religious or personal beliefs ${ }^{3}$. Therefore it may be better to restrict blood transfusion in dire necessity only.

The successful outcomes of total knee athroplasty require adequate intra operative haemostasis in order to avoid haematoma formation and minimize blood loss through suction drains. Achieving satisfactory post operative range of movements also depend on soft tissue haemostasis. Persistent bleeding after surgery can cause pain, wound haematoma, seroma formation and arthrofibrosis leading to sub-optimal outcomes after surgeries $^{4}$. So, it is important to consider minimise blood loss during surgeries around the hip joint. Efforts have been made to develop biological methods of haemostasis during the procedure. Tranexamic acid is well accepted haemostatic drug during coronary artery bypass surgery, epistaxis, menorrahagia, in haemophilia patients and dentistry. This study was aimed to ascertain the effectiveness of tranexamic acid in minimizing the intra operative and post operative blood loss in total knee arthroplasty.

\section{Material and methods}

This was a prospective randamized case and control study. The study period was 4 months from August 2013 to November 2013. A total number of 30 subjects who underwent total knee replacement were enrolled in the study. The written informed consent was taken from the patients who were included in the study.

The preoperative haemoglobin was assessed in all the patients. The patients were grouped as treatment(case) group and control group. The randomization was done by the rules of odds and even. In 15 
subjects of treatment group, a single dose of tranexamic acid, 10miligram per Kg bodyweight was given intravenously. The second group included the remaining 15 subjects in whom tranexamic acid was not given was considered as control group.

The patient under 50 years of age and the patients with renal failure, with upper genitourinary bleeding, with subarachnoid bleed and with acquired colour vision defect were excluded from study.

The 30 patients were operated by single surgeons. The cases of treatment and control group were selected by purposive sampling.

Injection tranexamic acid was administered in a dose of $10 \mathrm{mg} / \mathrm{kg}$ as bolus injection (treatment group) given slow intravenously over 5 minutes. The heart rate, respiratory rate and blood pressure were checked and charted intraoperatively and postoperatively.

A single brand of tranexamic acid from a reputed firm was used in all cases in order to minimize the brand related bias and for standardization. Intaoperative blood loss was calculated by galvanometric method ${ }^{20}$, weighing the sponges used and soiled by blood during surgery and measuring the amount of blood collected in suction apparatus used during the surgery.

The venous blood samples were collected from all the patients preoperatively and post operatively for determination of haemoglobin level. Postoperatively the drained fluid collected in the drain was also measured till the drain were removed.

The haemoglobin level was assessed post operatively and was compared with preoperative haemoglobin level. The data were analyzed with Fisher exact test.

The patients were followed up till they were discharged from the hospital and were observed specifically for the symptoms and signs of deep vein thrombosis.

\section{Results:}

There were 30 patients in our study group of which, $15(50 \%)$ patients received tranexamic acid were in the treatment group and remaining $15(50 \%)$ patients who did not receive the drug were in the control group

Table 1: Distribution of patients

\begin{tabular}{|l|l|l|}
\hline Drug & Total & Percentage \\
\hline Control & 15 & 50 \\
\hline Treatment & 15 & 15 \\
\hline Total & 30 & 100 \\
\hline
\end{tabular}

Out of 30 patients included in the study 20 were females and 10 were males.

\section{A. Intraoperative blood loss:}

In the treatment group, 10 patients out of 15 had blood loss below 400ml, and 5 patients had blood loss more than $400 \mathrm{ml}$. In control group 2 patients out of 15 had blood loss below $400 \mathrm{ml}$. And 13 patients had blood loss more than 400ml(Table 2)

Table 2:

\begin{tabular}{|l|l|l|l|l|l|}
\hline & $\begin{array}{l}300- \\
400 \mathrm{ml}\end{array}$ & $\begin{array}{l}400- \\
500 \mathrm{ml}\end{array}$ & $\begin{array}{l}500- \\
600 \mathrm{ml}\end{array}$ & $>600 \mathrm{ml}$ & Total \\
\hline $\begin{array}{l}\text { Treatm } \\
\text { ent }\end{array}$ & 10 & 2 & 1 & 2 & 15 \\
\hline control & 2 & 3 & 2 & 8 & 15 \\
\hline $\begin{array}{l}\text { P value } \\
\text { during PFN fixation. }\end{array}$ & & & & \\
\hline
\end{tabular}

\section{B. Post-operative blood loss:}

Drain was kept for all patients who underwent total knee replacemnt. Most of the dains are removed within 24 hours. The fluid collected in the post-operative drains were measured.

Of 30 patients of TKR group, tranexamic acid was received by 15 patients. In the treatment group 8 patients out of 15 patients had fluid(blood) drain below $100 \mathrm{ml}$ on the first post operative day. In control group 13 patients out of 15 had drained fluid more than $100 \mathrm{ml}$ on the first postoperative day, only 2 patients had less than $100 \mathrm{ml}$ drain. 
Table 5: Drain on the first post operative day following TKR:

\begin{tabular}{|c|c|c|c|c|c|}
\hline & $\begin{array}{l}50- \\
100 \mathrm{ml}\end{array}$ & $\begin{array}{l}100- \\
150 \mathrm{ml}\end{array}$ & $\begin{array}{l}150- \\
200 \mathrm{ml}\end{array}$ & $>200 \mathrm{ml}$ & Total \\
\hline Treatment & 8 & 3 & 2 & 2 & 15 \\
\hline Control & 2 & 3 & 3 & 7 & 15 \\
\hline Total & 10 & 6 & 5 & 9 & 30 \\
\hline \multicolumn{6}{|c|}{$\begin{array}{l}\mathrm{P} \text { value } 0.0001 \text {.significant decrease in post operative blood } \\
\text { loss noted. }\end{array}$} \\
\hline
\end{tabular}

\section{Change in the haemoglobin level:}

In patients who had TKR in the treatment group, 12 out of 15 patients had preoperative and post operative $\mathrm{Hb}$ difference less than $1 \mathrm{mg} / \mathrm{dl}$. In the control group, 13 out of 15 patients had preoperative and post operative $\mathrm{Hb}$ difference more than $1 \mathrm{mg} / \mathrm{dl}$.

Table 7: Difference between Pre and Post Operative Haemoglobin level:

\begin{tabular}{|c|c|c|c|}
\hline Pre-op Hb & Treatment & Control & Total \\
\hline$<1$ & 12 & 2 & 14 \\
\hline $1.1-2$ & 2 & 11 & 13 \\
\hline $2.1-3$ & 1 & 1 & 2 \\
\hline$>3$ & 0 & 1 & 1 \\
\hline Total & 15 & 15 & 30 \\
\hline
\end{tabular}

\section{Discussion}

Tranexamic acid is an anti fibrinolytic drug which by competetive inhibition prevents conversion of plasminogen to plasmin and thereby prevents the breakdown of clot. Both procoagulative factors and fibrinolysis are activated by surgical trauma ${ }^{21}$. In major surgical procedures large amounts of tissues will be exposed to injury. These tissues will release enzymes, primarily tPA [tissue plasminogen activator] activating the fibrinolytic system ${ }^{22}$. The fibrinolytic response is most pronounced intra operatively and early postoperatively. The half life of tranexamic acid is 180 minutes which would cover the duration of surgery.

We made no attempt to evaluate postoperative hematomas, since one of the previous studies had noted no significant difference in the amounts of the hematomas between patients treated with tranexamic acid or placebo $^{24}$.

In this study we found a significant decrease in the post operative blood loss as well.

The need for blood transfusion was not compared, since no clear parameters had been defined in either group for the indications for transfusion and, therefore, was susceptible to bias. But we found that transfusion requirement was less in cases when tranexamic acid was used.

we did not notice any incidence of deep vein thrombosis. This result of ours could be explained based on the research on tranexamic acid by hippala.et al which states that fibrinolytic activity in vein was not affected by tranxemic acid. It should be noted here that tranexamic acid does not promote clot formation but simply stabilizes the clot that has formed.

\section{Conclusion:}

We conclude that, as tranexamic acid reduced the intra and post operative bleeding in our patients who underwent total knee arthroplasty, Its use can be extended to other major orthopaedic surgeries. Prophylactic use of tranexamic acid also provides effective, safe and economical method for reducing blood loss and also in reducing the financial burden in terms of expenses incurred on blood transfusion. Tranexamic acid helps in reducing blood transfusion complications.

\section{Reference}

[1]. Feagan Bg, wong CJ, et al.transfusion practices for elective orthopaedic surgery CMAJ 2002;166(3):310

[2]. Ecker ML, Lotke PA(1993) Wound healing complications. In rand JA (ed) total knee arthroplasty.reven New York.

[3]. VamvakasEC, Blajchman MA.transfusion-related immunomodulation(TRIM); an update.Blood rev 2007;21:327-48.

[4]. flohe $\mathrm{S}$ Kobbe $\mathrm{p}$ et al.Immunological reactions seconday to blood transfusion.Injury 2007;38:1405-8

[5]. Seyyed Morteza Kazemi, MD; et.al: The effect of TA on reducing blood loss in cementless total hip arthroplasty under epidural anesthesia. 2010;33(1):17.

[6]. Gustav Ekba ck, MD et.al; TA reduces blood loss in total hip replacement surgery (anesth analg 2000;91:1124-30).

[7]. M. A. Claeys, et.al: Reduction of blood loss with TA in primary total hip replacement surgery department of anaesthesiology, Universitair Ziekenhuis Brussel. Acta chir belg, 2007, 107, 397-401

[8]. P. J. Zufferey1 2, M. Miquet1, et.al: Tranexamic acid in hip-fracture surgery. British Journal of Anaesthesia 104 (1): 23-30 (2010)

[9]. Jagwanth Singh et.al: TA on blood loss during total hip arthroplasty. Journal of orthopaedic surgery 2010:18(3): 282-6

[10]. Hippala S, strid L wenerstrad M et al. Tranexamic acid reduces perioperative blood loss associated with total knee replacement.

[11]. Mavis N. Schorn at al Measurement of Blood Loss: Review of the Literature 
[12]. Zhi-Gao Yang, MD, Wei-Ping Chen et al:Effectiveness and Safety of Tranexamic Acidin Reducing Blood Loss in Total KneeArthroplasty: A Meta-Analysis

[13]. M. Sadeghi and A. Mehr-Aein et al.Does a single bolus dose of tranexamic acid blood loss and transfusion requirements during hip fracture surgery.Prospective randamised double blind study in 67 patients.

[14]. Göran Benoni1, Hans Fredin at al.Blood conservation with tranexamic acid in total hip Arthroplasty Acta Orthop Scand 2001; 72 (5): $442-448$

[15]. MC Hynes, P Calder et al.The use of tranexamic acid to reduce blood loss duringtotal hip arthroplasty: an observational study

[16]. Henrik Husted1, Lars Blønd et al.Tranexamic acid reduces blood loss and blood transfusionsin primary total hip arthroplasty, Acta Orthop Scand 2003; 74 (6): 665-669

[17]. Torsten Johansson1, Lars-Göran et al.Tranexamic acid in total hip arthroplasty saves blood and money A randomized, double-blind study in 100 patients. Acta Orthopaedica 2005; 76 (3): 314-319

[18]. Göran Benoni1, Stefan Lethagen et al Tranexamic acid, given at the end of the operation, does not reduce postoperative blood loss in hip arthroplasty. Acta Orthop Scand 2000; 71 (3): 250-254

[19]. Raimo O Niskanen et al Tranexamic acid reduces blood loss in cemented hip arthroplasty A randomized, double-blind study of 39 patients with osteoarthritis. Acta Orthopaedica 2005; 76 (6): 829-832

[20]. Marcel H. Lee, DVM et al. Quantification of Surgical Blood Loss Veterinary Surgery 35:388-393, 2006

[21]. Dahl OE. The role of the pulmonary circulation in the regulation of coagulation and fibrinolysis in relation to major surgery. $\mathrm{J}$ Cardiothorac Vasc Anesth 1997;11:322-8.

[22]. Kluft C, Verheijen JH, Jie AF, et al. The postoperative fibrinolytic shutdown: a rapidly reverting acute phase pattern for the fastacting inhibitor of tissue-type plasminogen activator after trauma. Scand J Clin Lab Invest 1985;45:605-10.

[23]. Jansen AJ, Andreica S, Claeys M, D'Haese J, Camu F, Jochmans K. Use of tranexamic acid for an effective blood conservation strategy after total knee arthroplasty. Br J Anaesth. 1999 Oct; 83(4):596-601.

[24]. Benoni G, Fredin H, Knebel R, Nilsson P. Blood conservation with tranexamic acid in total hip arthroplasty: a randomized, doubleblind study in 40 primary operations.. Acta Orthop Scand. 2001 Oct;72(5):442-448.

[25]. MacGillivray RG, Tarabichi SB, Hawari MF, Raoof NT. Tranexamic acid to reduce blood loss after bilateral total knee arthroplasty: a prospective, randomized double blind study. J Arthroplasty. 2011 Jan;26(1):24-8. Epub 2010 Feb 19.

[26]. Orpen NM, Little C, Walker G, Crawfurd EJ. Tranexamic acid reduces early post-operative blood loss after total knee arthroplasty: a prospective randomised controlled trial of 29 patients. Knee. 2006 Mar;13(2):106-10. Epub 2006 Feb 17.

[27]. Tanaka N, Sakahashi H, Sato E, Hirose K, Ishima T, Ishii S. Timing of the administration of tranexamic acid for maximum reduction in blood loss in arthroplasty of the knee. J Bone Joint Surg Br. 2001 Jul;83(5):702-5.

[28]. Veien M, Sørensen JV, Madsen F, Juelsgaard P. Tranexamic acid given intraoperatively reduces blood loss after total knee replacement: a randomized, controlled study. Acta Anaesthesiol Scand. 2002 Nov;46(10):1206-11 